\title{
Current recommendations for the treatment of rhinosinusitis. Role of cefuroxime axetil
}

\author{
Aktualne zalecenia dotyczące leczenia zapalenia błony śluzowej nosa i zatok przynosowych. \\ Rola aksetylu cefuroksymu
}

\author{
Department of Paediatrics, Paediatric Nephrology and Allergology, Military Institute of Medicine, Warsaw, Poland. Head of the Department: Institute Professor Bolesław Kalicki, MD, PhD \\ Correspondence: Agata Będzichowska, Department of Paediatrics, Paediatric Nephrology and Allergology, Military Institute of Medicine, Szaserów 128, 04-141 Warsaw, Poland, \\ e-mail: abedzichowska@wim.mil.pl
}

\begin{abstract}
Rhinosinusitis is among the most prevalent respiratory infections occurring both in children and adults. The disease characteristically presents with nasal obstruction and discharge, pain or pressure and tenderness in the face, decreased sense of smell, and coughing. Based on the duration of symptoms, the type of nasal secretion, and the natural course of the disease, it can be classified into three types: acute viral rhinosinusitis, acute post-viral rhinosinusitis, and bacterial rhinosinusitis. Recommended non-pharmacological interventions in affected patients include maintaining adequate hydration and ensuring access to fresh moist air. Patients can also benefit from symptomatic therapy with antipyretics, anti-inflammatory agents, analgesics, mucosal decongestants and anti-secretion agents. Antibiotic treatment is indicated only for acute bacterial rhinosinusitis. In Poland, the first-line antibiotic therapy is based on high doses of amoxicillin. Second-line antibiotics include cefuroxime axetil, amoxicillin with clavulanic acid, and anti-pneumococcal fluoroquinolones. The treatment should last 10 days. Cefuroxime axetil is an effective and safe antibiotic in the treatment of patients with rhinosinusitis. The drug is used primarily when first-line therapy proves unsuccessful, and always in cases of non-immediate hypersensitivity reactions to penicillins. The development of symptoms indicative of sinusogenic, orbital or intracranial complications requires the initiation of systemic treatment in the hospital setting.
\end{abstract}

Keywords: rhinosinusitis, treatment, antibiotic, cefuroxime axetil

Zapalenie błony śluzowej nosa i zatok przynosowych to jedna z najczęstszych infekcji układu oddechowego, występująca zarówno u dzieci, jak i u dorosłych. Do charakterystycznych objawów choroby należą: upośledzenie drożności nosa, wyciek z nosa, ból lub rozpieranie okolicy twarzy, zaburzenia powonienia, kaszel. Ze względu na czas trwania objawów, charakter wydzieliny oraz naturalny przebieg schorzenia dzielimy je na: ostre wirusowe zapalenie błony śluzowej nosa i zatok przynosowych, ostre powirusowe zapalenie błony śluzowej nosa i zatok przynosowych oraz bakteryjne zapalenie błony śluzowej nosa i zatok przynosowych. W przypadku wystąpienia infekcji postępowanie niefarmakologiczne powinno obejmować adekwatne nawodnienie pacjenta oraz dostęp do świeżego, wilgotnego powietrza. W leczeniu objawowym pomocne są także preparaty przeciwgorączkowe, przeciwzapalne, przeciwbólowe, obkurczające naczynia błony śluzowej oraz zmniejszające jej sekrecję. Stosowanie antybiotyku zalecane jest jedynie w ostrym bakteryjnym zapaleniu błony śluzowej nosa i zatok przynosowych. W Polsce antybiotykiem pierwszego wyboru jest amoksycylina w wysokich dawkach. Do antybiotyków drugiego wyboru zaliczamy aksetyl cefuroksymu, amoksycylinę z kwasem klawulanowym oraz fluorochinolony przeciwpneumokokowe. Leczenie powinno trwać 10 dni. Aksetyl cefuroksymu jest antybiotykiem skutecznym i bezpiecznym w leczeniu zapalenia błony śluzowej nosa i zatok przynosowych. Stosuje się go przede wszystkim w przypadku nieskuteczności leczenia pierwszego wyboru i zawsze w przypadku wystąpienia nadwrażliwości nienatychmiastowej na penicyliny. Wystąpienie objawów wskazujących na rozwijające się powikłania zatokopochodne, oczodołowe lub wewnątrzczaszkowe wymaga leczenia systemowego w warunkach szpitalnych.

Słowa kluczowe: zapalenie błony śluzowej nosa i zatok przynosowych, rhinosinusitis, leczenie, antybiotyk, aksetyl cefuroksymu 


\section{INTRODUCTION}

$\mathrm{R}$ hinosinusitis is one of the most prevalent disease entities both in the paediatric and adult populations. According to various sources rhinosinusitis is estimated to occur 2-5 times per year in adults, and up to 7-10 times per year in preschool and schoolchildren ${ }^{(1-4)}$. Acute rhinosinusitis is characterised by a sudden onset, and it typically runs a course of no more than 3 months. The inflammatory process affects the mucosa of the nasal cavities and paranasal sinuses. This is due to the fact that both these structures constitute a morphological and functional whole ${ }^{(4-6)}$.

Typical manifestations of the disease include nasal obstruction and discharge. Other symptoms potentially indicative of rhinosinusitis are pain and/or pressure and tenderness in the face, decreased sense of smell, and coughing ${ }^{(4-6)}$. Routine diagnostic work-up in rhinosinusitis does not comprise microbiological or imaging procedures ${ }^{(5,6)}$. Consequently, diagnosis is possible based on the characteristic clinical manifestations of the disease $\mathrm{e}^{(5-7)}$.

Depending on the duration of symptoms, the type of nasal secretion, and the natural course of the disease, it can be divided into:

- acute viral rhinosinusitis;

- acute post-viral rhinosinusitis;

- bacterial rhinosinusitis ${ }^{(5,6)}$.

Acute viral rhinosinusitis, also referred to as the common cold, is an infection with symptoms resolving within 10 days. The disease is most commonly caused by rhinoviruses, coronaviruses, respiratory syncytial virus (RSV), influenza viruses, parainfluenza viruses, and adenoviruses ${ }^{(5-8)}$. The activity of these pathogens results in damage to the ciliary epithelium, release of proinflammatory cytokines, and mucosal oedema ${ }^{(5,9-12)}$. By increasing vascular permeability, cytokines and mediators of the inflammatory response lead to mucosal oedema, increased production of secretion, and disorders in mucociliary transport, causing nasal obstruction. The process corresponds to the vascular component of the inflammatory response. This is followed by profuse serous discharge causing cough (stage characterised by congestion, oedema and exudation). The symptoms resolve spontaneously within 5 to 10 days $s^{(5,9-12)}$.

Post-viral rhinosinusitis results from excessive inflammatory response, with symptoms persisting over 10 days or worsening after 5 days of acute viral rhinosinusitis. The process corresponds to the cellular component of the inflammatory response. Post-viral rhinosinusitis is manifested clinically by severe thick mucosal or mucopurulent discharge, and persistent cough. In this case, the presence of mucopurulent discharge is not a manifestation of bacterial infection ${ }^{(5,9-12)}$. Bacterial rhinosinusitis should be diagnosed when three or more of the following symptoms are confirmed: purulent nasal discharge or purulent discharge in the nasal passages, severe local pain (with unilateral predominance), fever, elevated inflammatory markers, and deterioration of symptoms after an initial milder phase of illness ${ }^{(5,6,8)}$. The symptoms are typical of the third phase of the inflammatory response, the so-called destructive stage, which develops following bacterial superinfection ${ }^{(9,10)}$. In the majority of cases, it is caused by Streptococcus pneumoniae (26-35\%) and Haemophilus influenzae $(21-40 \%)^{(1,2,4,5,13)}$. Other pathogens, responsible for less than $20 \%$ of cases of bacterial rhinosinusitis, include Moraxella catarrhalis, Staphylococcus aureus and Streptococcus pyogenes ${ }^{(1,5,13)}$. The aetiology of infection is more complex in cases of chronic sinusitis and other chronic respiratory diseases (including cystic fibrosis, ciliary dyskinesia, and immune disorders). In such cases, the possibility of infection caused by Staphylococcus aureus or anaerobic pathogens should be considered ${ }^{(1,4,5,13)}$. It is estimated that $0.5-2 \%$ of adults and $5-13 \%$ of children with acute viral rhinosinusitis develop bacterial rhinosinusitis ${ }^{(5,6,14)}$.

\section{TREATMENT}

The recommendations for the treatment of rhinosinusitis presented in this paper are based on the 2012 European guidelines for the management of rhinosinusitis and nasal polyps (European Position Paper on Rhinosinusitis and Nasal Polyps, EPOS 2012), 2016 Polish recommendations for the management of community-acquired respiratory infections, and 2013 guidelines for the management of acute sinusitis published by the American Academy of Pediatrics $(\mathrm{AAP})^{(5,6,8)}$.

The aim of treatment in the first phase of rhinosinusitis should be to reduce oedema, congestion, pain and fever ${ }^{(4-7)}$. The basis for non-pharmacological management is access to fresh, cool air, which help to contract dilated blood vessels, thereby reducing oedema ${ }^{(4-7)}$. Useful therapeutic agents include antipyretics, anti-inflammatory agents, analgesics, decongestants and anti-secretion agents ${ }^{(4-7)}$. First-line treatment is based on non-steroidal anti-inflammatory drugs (NSAIDs), most commonly ibuprofen which, in addition to its central activity (inhibition of prostaglandin synthesis in the hypothalamus and nitric oxide in the spinal cord, resulting in pain and fever reduction) also produces peripheral anti-inflammatory effects. Naproxen is indicated for the treatment of adult patients with concomitant cardiovascular disorders (e.g. ischaemic heart disease, hypertension, pulmonary embolism, history of stroke). Paracetamol should be given to children with contraindications to NSAID treatment ${ }^{(4,5)}$.

The most widely used group of decongestants comprises intranasally administered imidazole derivatives including xylometazoline, oxymetazoline and naphazoline. They produce sympathomimetic effects, mainly by directly affecting the alpha-adrenergic receptors ${ }^{(4,5)}$. In addition, pseudoephedrine is recommended as an agent reducing mucosal congestion. The drug selectively stimulates alpha-1 receptors in blood vessels. However, as it demonstrates a certain degree of stimulatory action on the central nervous system, pseudoephedrine is not recommended for the treatment of children under the age of 12. Therapy with these decongestants should be limited to $3-5$ days on account of the possibility of 
adverse effects, the most common of which are dryness, secondary nasal mucosal swelling, and nosebleeds ${ }^{(4,5)}$.

Antisecretolytic drugs widely used in the therapy of rhinosinusitis also include older-generation antihistamines such as dimetindene, clemastine, hydroxyzine, and promethazine. Their anticholinergic effect reduces the secretion of mucus and post-nasal drip causing cough. The sedative effect induced by these drugs also appears to be beneficial, especially at night, in younger patients ${ }^{(5,15)}$. However, a different position is presented by the AAP. The authors of the 2013 recommendations advise against antihistamine treatment in children with rhinosinusitis who do not show allergy symptoms ${ }^{(8,16,17)}$.

Pseudoephedrine-containing medications combined with antihistamines are also allowed. The combination, which relieves the attacks of dry coughing induced by post-nasal drip due to viral rhinosinusitis, is recommended, for example, by the American College of Chest Physicians ${ }^{(15)}$.

In the second inflammatory stage (post-viral rhinosinusitis), the mucous secretion becomes thicker. Consequently, the basis for non-pharmacological management should be to provide patients with adequate hydration and ensure appropriate drainage of nasal cavities and paranasal sinuses through moisturisation of inhaled air. To this end, normal saline solution or isotonic water solution can be administered intranasally ${ }^{(4,5)}$.

Therapy with mucokinetic and mucolytic agents continues to be controversial, and the efficacy of these drugs in rhinosinusitis has not yet been substantiated by reliable clinical studies ${ }^{(4-6)}$. Both Polish and European guidelines approve the use of herbal secretolytic drugs in post-viral rhinosinusitis. Among them, the most convincing evidence has been obtained in clinical studies for a herbal therapeutic agent containing gentian root (Radix gentianae), cowslip blossoms including calyx (Primulae flos cum calycibus), sorrel herb (Rumicis herba), elder flower (Sambuci flos), and verbena herb (Herba verbenae $)^{(5,6)}$. However, since the drug contains alcohol, it should not be used in children under 6 years of age.

Another group of drugs recommended for the symptomatic treatment of both viral and bacterial rhinosinusitis comprises nasal corticosteroids. Multiple clinical studies have shown that treatment with drugs of this group for 7-14 days has a positive effect on reducing the inflammatory process, relieving nasal congestion, and facilitating drainage of the secretion $^{(4-6)}$. In Poland, the most popular topical nasal steroid - mometasone - is approved for the treatment of patients over 3 years of age.

According to therapeutic recommendations antibiotic treatment is indicated only for acute bacterial rhinosinusitis $^{(5,6,8)}$. The goals of antibiotic therapy in this condition are to eradicate bacteria from the nasal cavities and sinuses, promote the resolution of symptoms, and prevent the development of complications such as progression of the condition to a chronic state or involvement of adjacent structures $^{(5)}$. The first-line antibiotic in Poland is amoxicillin due to factors including its targeted spectrum of activity against the most prevalent pathogens responsible for rhinosinusitis: Streptococcus pneumoniae and Haemophilus influenzae $e^{(4-8)}$. To overcome the decreasing susceptibility of pneumococci to penicillin among the Polish population, amoxicillin should be administered in high doses (in adults and children over $40 \mathrm{~kg}$ : 1,500-2,000 mg orally every 12 hours, children under $40 \mathrm{~kg}$ : 75-90 mg/kg/day in 2 divided doses, orally $\left.{ }^{(4-8)}\right)$.

If the clinical effect is satisfying, a course of treatment should last for 10 days $^{(5,6)}$.

Lack of improvement within 48 hours of the introduction of first-line antibiotic therapy is an indication for considering adjustment of primary treatment ${ }^{(5)}$. Failure to respond to amoxicillin may be due to the presence of an amoxicillin-resistant strain, complications associated with the infection or a possible non-bacterial cause of infection ${ }^{(5)}$. Amoxicillinresistant pathogens which may cause rhinosinusitis include highly penicillin-resistant pneumococci, $\beta$-lactamaseproducing Haemophilus influenzae, Staphylococcus aureus, and anaerobic bacteria ${ }^{(5)}$. In such cases, one of the secondline antibiotics should be considered, selected from a group including cefuroxime axetil, amoxicillin with clavulanate or anti-pneumococcal fluoroquinolones (moxifloxacin, levofloxacin $)^{(5,6,8)}$. Such treatment should also be initiated in patients with early recurrence of rhinosinusitis ${ }^{(5)}$. The antibiotic should be taken for 10 days ${ }^{(5,6)}$.

In kindergarten or preschool children treated with antibiotics, particularly amoxicillin, during 4 weeks preceding the onset of rhinosinusitis, and children under 2 years of age, the recommendation is to use amoxicillin with clavulanate for the management of bacterial rhinosinusitis as an empirical treatment ${ }^{(5,8)}$. The dose of amoxicillin/clavulanic acid for oral administration should be expressed as amoxicillin, as described above. If vomiting occurs, or oral administration is not possible, a single dose of ceftriaxone $(50 \mathrm{mg} / \mathrm{kg})$ should be administered intravenously, to be followed by further treatment, preferably via the oral route ${ }^{(8)}$.

In the event of a non-immediate (non-type I) hypersensitivity reaction to penicillins, cefuroxime axetil is the drug of choice (adults and children over $40 \mathrm{~kg}: 2 \times 500 \mathrm{mg} /$ day, children under $40 \mathrm{~kg}: 30 \mathrm{mg} / \mathrm{kg} /$ day in 2 divided doses, orally, for a period of 10 days, not exceeding a single dose of $500 \mathrm{mg}^{(5,6)}$.

In cases of immediate (type I) hypersensitivity to beta-lactam antibiotics, clarithromycin is recommended (adults and children over $40 \mathrm{~kg}$ : 250-500 mg every 12 hours, children under $40 \mathrm{~kg}: 15 \mathrm{mg} / \mathrm{kg} /$ day in 2 divided doses, orally). The treatment is continued for 10 days ${ }^{(5,6)}$. According to the AAP recommendations, children under 1 year of age with moderate or severe rhinosinusitis, showing type I hypersensitivity reactions, can be treated with clindamycin or linezolid combined with cefixime ${ }^{(8)}$.

In adults with immediate hypersensitivity to beta-lactam antibiotics, anti-pneumococcal fluoroquinolones can be used: $400 \mathrm{mg}$ moxifloxacin daily or $500 \mathrm{mg}$ levofloxacin daily in 


\begin{tabular}{|c|c|c|c|c|c|}
\hline Antibiotic & $\begin{array}{c}\text { Dose and duration } \\
\text { of treatment }\end{array}$ & $\begin{array}{c}\text { Number } \\
\text { of reviewed studies }\end{array}$ & $\begin{array}{c}\text { Number } \\
\text { of study patients }\end{array}$ & $\begin{array}{c}\text { Efficacy of treatment } \\
\text { [\%], median (range) }\end{array}$ & $\begin{array}{c}\text { Side effects [\%] } \\
\text { (range) }\end{array}$ \\
\hline Cefuroxime axetil & $\mathbf{2} \times \mathbf{1 2 5}-\mathbf{2 5 0} \mathbf{~ m g , 5 - 1 0 ~ d a y s ~}$ & $\mathbf{1 0}$ & $\mathbf{1 , 8 8 8}$ & $\mathbf{8 5}(\mathbf{6 3 - 9 1 . 1 )}$ & $\mathbf{8 . 1 - 3 4 . 2}$ \\
\hline Telithromycin & $1 \times 800 \mathrm{mg}, 5-10$ days & 7 & 1,563 & $80.9(72.9-91.1)$ & $21.3-46.9$ \\
\hline Amoxicillin/clavulanic acid & $2 \times 500-875 \mathrm{mg} / 125 \mathrm{mg}, 6-14$ days & 7 & 973 & $77.4(50-93)$ & $17-51.1$ \\
\hline Levofloxacin & $1 \times 500-750 \mathrm{mg}, 5-10$ days & 6 & 1,050 & $91.4(23.4-93.9)$ & $15.3-39.8$ \\
\hline Moxifloxacin & $1 \times 400 \mathrm{mg}, 5-10$ days & 5 & 937 & 86 & $16.9-38.2$ \\
\hline Clarithromycin & $2 \times 500 \mathrm{mg}, 10-14$ days & 5 & 835 & $85(79-93.5)$ & $28-48.4$ \\
\hline
\end{tabular}

Tab. 1. Efficacy and adverse effects of antibiotics used in the treatment of acute rhinosinusitis - elaborated by the authors based on a systematic review published in 2015 (Sng and Wang ${ }^{(26)}$ )

single doses for 5-10 days ${ }^{(5,6)}$. On account of the observed inadequate eradication of Streptococcus pneumoniae and Haemophilus influenzae azithromycin is strongly discouraged in the treatment of rhinosinusitis in children ${ }^{(5,18,19)}$.

In addition, according to the EPOS 2012 guidelines, standard therapy in adult patients with chronic rhinosinusitis without nasal polyps, as described above, can be complemented with adjuvant treatment with the OM-85 BV oral bacterial lysate ${ }^{(6)}$.

Treatment failure is an indication for a laryngological consultation $^{(5,6,8)}$. Surgical therapy is required only in a small group of patients, and it should be used as the treatment of last resort, after all possibilities of conservative therapy have been exhausted. Adenoidectomy and maxillary sinus wash are among the most commonly performed procedures in children. The last line of treatment, employed in patients experiencing a recurrence of symptoms after the therapeutic interventions described above, is functional endoscopic sinus surgery (FESS) ${ }^{(3,4,20)}$.

The development of symptoms indicative of sinusogenic, orbital or intracranial complications requires the initiation of systemic treatment in the hospital setting ${ }^{(5,8)}$. Warning signs in such cases should be considered to include eyelid swelling, exophthalmos, restricted ocular motility, double vision, visual acuity impairment, severe pain and swelling of the frontal area, symptoms of meningitis, and focal neurological symptoms $\mathrm{s}^{(5,6,8,14)}$.

\section{EFFICACY AND SAFETY OF CEFUROXIME AXETIL IN THE TREATMENT OF RHINOSINUSITIS}

Cefuroxime axetil is an antibiotic with good efficacy and safety in the treatment of rhinosinusitis both in children and in adults, as shown by multiple clinical trials ${ }^{(21-26)}$.

In 2001, Olszewski and Kuśmierczyk conducted a study in a group of 65 adult Poles, demonstrating over $90 \%$ efficacy of cefuroxime axetil used at doses of $2 \times 500 \mathrm{mg}$ in a 4-day antibiotic regimen for the treatment of acute maxillary sinusitis ${ }^{(21)}$. Similar observations were also made by other authors including: Namyslowski et al. ${ }^{(22)}-88 \%$ clinical efficacy rate of 14-day therapy $(2 \times 500 \mathrm{mg})$ in a group 10-day treatment $(2 \times 250 \mathrm{mg})$ in a group 542 patients, and Siegert et al. ${ }^{(24)}-91 \%$ clinical efficacy rate of 10-day therapy $(2 \times 250 \mathrm{mg})$ in 498 patients with rhinosinusitis. In a summary statement published in 2004 by Sinus and Allergy Health Partnership, the estimated clinical efficacy of empirical therapy with cefuroxime axetil in both children and adults was $85 \%{ }^{(25)}$.

A comprehensive metaanalysis of 31 randomised trials assessing the efficacy and safety of antibiotics used in rhinosinusitis was conducted in 2015 by Sng i Wang ${ }^{(26)}$. Among the antibiotics compared in the study, cefuroxime axetil showed high clinical efficacy and had the lowest relative rate of adverse reactions (Tab. 1).

\section{CONCLUSIONS}

Although rhinosinusitis is one of the most prevalent disease entities, in the vast majority of cases it requires only symptomatic treatment. In patients diagnosed with bacterial rhinosinusitis, treatment should be tailored precisely to the individual so as to avoid potentially dangerous complications. Cefuroxime axetil should be recognised as an effective and safe antibiotic indicated for the treatment of rhinosinusitis especially in patients who fail to improve with first-line treatment, and always in cases of non-immediate hypersensitivity to penicillins.

\section{Conflict of interest}

The authors do not declare any financial or personal links with other persons or organisations that might adversely affect the content of the publication or claim any right to the publication.

\section{References}

1. Miśkiewicz-Orczyk K, Kycia-Marków M, Grzanka A et al.: Interdyscyplinarne postępowanie $\mathrm{w}$ diagnostyce i leczeniu przewlekłego zapalenia zatok przynosowych. Probl Med Rodz 2011; 34: 35-39.

2. Hryniewicz W, Grzesiowski P, Kozielski J et al.: Rekomendacje diagnostyki i leczenia zakażeń układu oddechowego wg EBM 2008: 68-70.

3. Sobolewska M, Wojdas A: EPOS 2012 - zaskakujące nowości czy utrwalone standardy? Nowa Klin Laryngologia 2013; 20: 307-308. 
4. Wachnicka-Bąk A, Lipińska-Opałka A, Będzichowska A et al.: Zapalenie błony śluzowej nosa i zatok przynosowych - jedno z najczęstszych zakażeń górnych dróg oddechowych. Pediatr Med Rodz 2014; 10: 25-31.

5. Hryniewicz W, Albrecht P, Radzikowski A (eds.): Rekomendacje postępowania w pozaszpitalnych zakażeniach układu oddechowego. Narodowy Program Ochrony Antybiotyków, Narodowy Instytut Leków, Warszawa 2016: 81-92.

6. Fokkens WJ, Lund VJ, Mullol J et al.: European position paper on rhinosinusitis and nasal polyps 2012. Rhinol 2012; 50 (Suppl 23): 1-136.

7. Samoliński B, Gotlib T, Pietruszewska W et al.: Postępowanie w ostrym zapaleniu zatok przynosowych w praktyce lekarza rodzinnego. Stanowisko 4 Towarzystw (StanForT) (na podstawie EPOS 2012). Alergologia Polska - Polish Journal of Alergology 2014; 1: 87-93.

8. Wald ER, Applegate KE, Bordley C et al.: Clinical practice guideline for the diagnosis and management of acute bacterial sinusitis in children aged 1 to 18 years. Pediatrics 2013; 132: e262-e280.

9. Paczwa P: Humoralne i nerwowe mechanizmy zapalenia w obrębie dróg oddechowych. Probl Laryngol w Codziennej Praktyce Lek 1998; 10: 2-7.

10. Radzikowski A, Albrecht P: Leczenie objawowe zakażeń dróg oddechowych - podstawy patofizjologiczne i strategia postępowania. Pediatr Pol 1998; 73: 1-8.

11. Wald E: Sinusitis. In: Long SS, Pickering LK, Prober CG (eds.): Principles and Practice of Pediatric Infectious Diseases. Churchill Livingstone, New York 2003: 200-205.

12. Rudack C, Hauser U, Wagenmann $M$ et al.: [Cytokine pattern in various forms of sinusitis]. Laryngorhinootologie 1998; 77: 34-37.

13. Brook I: Microbiology of sinusitis. Proc Am Thorac Soc 2011; 8: 90-100.

14. Piltcher OB, Kosugi EM, Sakano E et al.: How to avoid the inappropriate use of antibiotics in upper respiratory tract infections? A position statement from an expert panel. Braz J Otorhinolaryngol 2018; 84: 265-279.

15. Bolster DC: Cough suppressant and pharmacologic protussive therapy: ACCP evidence-based clinical practice guidelines. Chest 2006; 129 (Suppl): 238S-249S.
16. De Bruyne $P$, Christiaens $T$, Boussery $\mathrm{K}$ et al.: Are antihistamines effective in children? A review of the evidence. Arch Dis Child 2017; 102: 56-60.

17. Runkle K: Decongestants, antihistamines and nasal irrigation for acute sinusitis in children. Pediatr Child Health 2016; 21 : 143-144.

18. Dagan R, Johnson CE, McLinn S et al.: Bacteriologic and clinical efficacy of amoxicillin/clavulanate vs. azithromycin in acute otitis media. Pediatr Infect Dis J 2000; 19: 95-104.

19. Hoberman A, Dagan R, Leibowityz E et al.: Large dosage amoxicillin/clavulanate, compared with azithromycin, for the treatment of bacterial acute otitis media in children. Pediatr Infect Dis J 2005; 24: 525-532.

20. Rygalska B, Szczygielski K: Biofilm bakteryjny - nowe wyzwanie dla lekarzy zajmujących się problemem przewlekłego zapalenia zatok przynosowych. Nowa Klin Laryngologia 2013; 20: 367-368.

21. Olszewski J, Kuśmierczyk K: [Therapeutic efficacy assessment of cefuroxime axetil in short 4 day course of empirical antibiotic therapy in patients with bacterial infections of upper respiratory tract and otitis media]. Otolaryngol Pol 2001; 55: 489-496.

22. Namyslowski G, Misiolek M, Czecior E et al.: Comparison of the efficacy and tolerability of amoxycillin/clavulanic acid $875 \mathrm{mg}$ b.i.d. with cefuroxime $500 \mathrm{mg}$ b.i.d. in the treatment of chronic and acute exacerbation of chronic sinusitis in adults. J Chemother 2002; 14: 508-517.

23. Burke T, Villanueva C, Mariano $\mathrm{H}$ Jr et al.: Comparison of moxifloxacin and cefuroxime axetil in the treatment of acute maxillary sinusitis. Sinusitis Infection Study Group. Clin Ther 1999; 21: 1664-1677.

24. Siegert R, Gehanno P, Nikolaidis P et al.: A comparison of the safety and efficacy of moxifloxacin (BAY 12-8039) and cefuroxime axetil in the treatment of acute bacterial sinusitis in adults. The Sinusitis Study Group. Respir Med 2000; 94: 337-344.

25. Anon JB, Jacobs MR, Poole MD et al.; Sinus and Allergy Health Partnership: Antimicrobial treatment guidelines for acute bacterial rhinosinusitis. Otolaryngol Head Neck Surg 2004; 130 (Suppl): 1-45.

26. Sng WJ, Wang DY: Efficacy and side effects of antibiotics in the treatment of acute rhinosinusitis: a systematic review. Rhinology 2015; 53: 3-9. 